\title{
ANALYSIS OF DIDACTIC VALUES IN THE TEACHER'S DIARY BY NITHIWAT THARATHORN
}

\author{
Muhamad Yusuf \\ Universitas Muhammadiyah Prof. Dr. Hamka \\ Trie Utari Dewi \\ Universitas Muhammadiyah Prof. Dr. Hamka \\ Jl. Tanah Merdeka, No. 20, Jaktim, 13830, Indonesia; \\ e-mail: yusufperss@gmail.com
}

\begin{abstract}
The Teacher's Diary film by Nithiwat Tharathorn raises the theme of the struggle of teachers who teach in remote school. The problem discussed in this research is didactic value. The researcher describes the didactic values found in the depiction of characters through actions, speech and mind. Didactic value analysis in this film used Ali's theory. The method used is descriptive qualitative content analysis approach. The results showed that the didactic values contained in the film The Teacher's Diary, namely intellectual / intelligence value, skill value, self-esteem value, social values / community relations / association, moral value, beauty value, divine / religious value, self-control value / emotional stability, value of behavior / customs of courtesy, the value of will / desire or ideals. Based on the research results, it can be concluded that the didactic values in this film can be used as a reflection or example for teachers to teach and educate students and understand the meaning of teacher in a complete perspective.
\end{abstract}

Keywords: Didactic Value, The Teacher's Diary, Film.

Article History: Received: 16/04/2020; Revised: 11/06/2020; Accepted: 26/06/2020; Published: 16/07/2020

How to Cite (MLA 7 $7^{\text {th }}$ : Yusuf, Muhamad dan Trie Utari Dewi. "Analysis of Didactic Values in The Teacher's Diary by Nithiwat Tharathorn." Hortatori Jurnal Pendidikan Bahasa dan Sastra Indonesia vol. 4, no. 1, 2020, 14-23. Print/Online. Copyrights Holder: Muhamad Yusuf dan Trie Utari Dewi. First Publication: Hortatori Jurnal Pendidikan Bahasa dan Sastra Indonesia (2020).

This work is licensed under a Creative Commons Attribution-ShareAlike 4.0 International License.

\section{Pendahuluan}

Dewasa ini, masyarakat lebih memilih untuk menonton film demi mencari hiburan. Alasan-alasan khusus mengapa seseorang menyukai film, karena adanya unsur usaha manusia untuk mencari hiburan dan meluangkan waktu (Arifin dalam Anggriani et al., 2015). Masyarakat memiliki caranya masingmasing untuk mengisi waktu luang. Ada yang mengerjakan hobi dengan beraktivitas di luar ruangan seperti berolahraga namun ada juga yang lebih memilih pergi ke bioskop untuk menonton film. Melalui tontonan film dengan durasi waktu tertentu menjadi sarana rekreasi yang menyenangkan karena film lebih singkat sedangkan novel butuh waktu lama. Itu menunjukkan di zaman modern ini, film sedang sangat digemari oleh masyarakat. Hal tersebut senada dengan Elvianaro yang menjelaskan bahwa pada dasarnya film merupakan alat audio visual yang menarik perhatian orang banyak, karena dalam film itu selain memuat adegan yang terasa hidup juga adanya sejumlah kombinasi antara suara, tata warna, kostum, dan panorama yang indah (dalam Anggriani et al., 2015).

Film juga merupakan salah satu bentuk karya sastra dengan media yang berbeda, dan keduanya memiliki fungsi yang sama. Ketika kita membaca suatu karya sastra atau menonton film, ada kemiripan atau kesamaan yang melekat di antara keduanya, yaitu hiburan dan manfaat yang diperoleh dari isi atau jalan cerita. Hal ini sebagaimana yang diungkapkan oleh Wellek-Warren bahwa sastra memiliki unsur kesenangan dan manfaat (dalam Sari and Mayrita, 2017:2). Sejalan dengan itu, Winokur menyebutkan 
adanya dua fungsi utama dari sebuah film, yaitu fungsi hiburan (entertainment) dan fungsi didaktisme (deductism) (dalam Riyadi, 2014:244).

Film The Teacher's Diary karya Nithiwat Tharathorn mengangkat kisah nyata tentang dua orang tidak saling mengenal yang mengajar di sekolah apung bernama "Bann Ko Jatson School (Floating Class Branch)" di Li District, Lamphun Province di Utara Thailand. Dalam film tersebut, dapat ditemukan halhal yang akan memberikan penonton kepuasan batin tentang arti dari sosok seorang guru. Film ini adalah film tentang perjuangan guru yang mengajar di sekolah kapal di daerah terpencil. Dengan segala upaya dan keterbatasan yang dimiliki di sana, dapat dipahami bahwa menjadi seorang guru sangatlah tidak mudah. Namun, melihat perjuangan guru yang ada di dalam film akan membantu penonton agar bijak dalam melihat persoalan dan bagaimana cara untuk menyelesaikan segala permasalahan yang ada.

Penelitian terhadap film The Teacher's Diary dirasa sangat penting untuk dilakukan. Hal ini dikarenakan, film tersebut menggambarkan sosok guru yang dapat dijadikan contoh atau teladan. Masingmasing guru memiliki caranya tersendiri untuk membuat murid-muridnya paham atas apa yang diajarkan. Sebagai contoh, ketika mengajarkan materi daya mengapung, anak-anak diajarkan metode praktik langsung dengan cara masuk ke kolam renang agar lebih mengerti dan paham karena ini metode menghafal di luar kepala. Ketika ingin memperkenalkan diri, murid-murid diajarkan sambil menggunakan gerakan supaya dapat mengingat dengan mudah. Dari contoh-contoh tersebut, dapat memberikan inspirasi bagi penonton, khususnya para guru agar dapat berkreasi dan berinovatif dalam melakukan proses pembelajaran sehingga dapat memberikan pemahaman yang baik kepada siswa.

Selain itu, film The Teacher's Diary juga mengajarkan pada penonton bahwa tugas guru bukan hanya mengajar melainkan juga mendidik. Guru menjadi orang tua kedua bagi murid-muridnya di sekolah. Guru memiliki tanggung jawab moral yang berat dalam mendidik karakter siswa. Didikan yang benar dan tepat dapat memberikan hasil yang baik untuk masa depan mereka. Guru juga tidak boleh mempersoalkan seberapa banyak atau sedikit murid yang dimiliki akan tetapi harus dapat memberikan pendidikan yang baik atas hak mereka untuk memperolehnya. Hal-hal yang demikian, sangat penting untuk pengetahuan calon guru atau para guru dalam mengajar.

Film memiliki nilai-nilai yang sangat bermanfaat untuk kita terapkan dalam kehidupan seharihari, salah satunya ialah nilai didaktis. Istilah didaktis lebih dikenal dengan nilai pendidikan karena berkaitan dengan pendidikan dan pengajaran. Seperti pendapat Semi mengatakan bahwa didaktik adalah pendidikan dengan pengajaran yang dapat mengantarkan pembaca kepada sesuatu arah tertentu (dalam Endeh, 2017). Setelah membaca atau menonton karya sastra, dapat menambah pengalaman dan perubahan cara berpikir atau bertindak dalam diri seseorang menuju ke arah yang lebih baik lagi.

Dalam penelitian ini, peneliti membahas nilai-nilai didaktis yang terdapat pada film The Teacher's Diary karya Nithiwat Tharathorn dengan mengacu pada teori Ali yang mengemukakan bahwa nilai-nilai yang diajarkan guru dalam pengajaran adalah mencakup, (1) nilai intelektual/kecerdasan, (2) nilai keterampilan, (3) nilai harga diri, (4) nilai sosial/hubungan masyarakat/pergaulan, (5) nilai moral, (6) nilai keindahan, (7) nilai ketuhanan/keagamaan, (8) nilai penguasaan diri/kestabilan emosi, (9) nilai tingkah laku/adat sopan santun, (10) nilai kehendak/kemauan atau cita-cita (dalam Apriawati, 2016).

Peneliti akan mengkaji nilai didaktis dalam film tersebut melihat dari sosok guru melalui tindakan, ucapan, dan pikiran yang dalam proses pengajaran kepada murid-murid di sana sehingga menjadikan film tersebut banyak memberikan inspirasi bagi penonton, sebagai refleksi seorang guru dalam mengajar dan mendidik siswa, dan memahami makna guru dalam perspektif yang utuh. Film ini belum pernah dikaji atau diteliti dalam sebuah penelitian sehingga membuat peneliti sangat tertarik menggunakan film ini yang membahas nilai didaktis. Kajian nilai didaktis sangat tepat digunakan karena akan banyak hal yang dikemukakan terkait dengan pengajaran dan pendidikan yang ada dalam film ini. Adapun penelitian yang pernah dilakukan terkait analisis didaktif adalah nilai didaktis pada film Jenderal Soedirman dan novel Sang Pencerah. Temuan yang diperoleh dalam penelitian tersebut di antaranya adalah nilai agama, nilai sosial, dan nilai kesusilaan/budi pekerti (Fitriani, 2017; Apriawati, 2016).

\section{Metode}

Metode yang digunakan dalam penelitian ini adalah deskriptif kualitatif dengan pendekatan content Analysis. Content analysis yaitu penelitian yang dilakukan terhadap informasi yang didokumentasikan dalam rekaman, baik gambar, suara ataupun tulisan. Metode penelitian deskriptif kualitatif karena data-data yang disajikan dalam penelitian ini berupa naratif deskriptif yang berasal dari 
studi kepustakaan dan bukan berupa angka-angka. Penelitian ini bertujuan untuk mendeskripsikan nilai-nilai didaktis dengan dianalisis menggunakan teori Ali. Objek penelitian yang digunakan yaitu film The Teacher's Diary karya Nithiwat Tharathorn tahun 2014 yang berdurasi 110 menit. Data-data yang digunakan dalam film tersebut berupa gambar, kata, kalimat/ungkapan pada monolog ataupun dialog yang sesuai dengan kajian nilai didaktis. Teknik dokumentasi digunakan dalam pengumpulan data dengan cara mendata setiap teks kalimat atau ungkapan yang termasuk ke dalam nilai didaktis pada film The Teacher's Diary. Selanjutnya dalam menganalisis data digunakan teknik simak dan catat. Sebelum dilakukan analisis, film disimak dengan baik lalu mencatat nilai-nilai didaktis yang terdapat dalam film tersebut, dan selanjutnya diklasifikasikan berdasarkan teori yang digunakan.

\section{Hasil dan Diskusi}

\section{Temuan Penelitian}

Dalam film The Teacher's Diary karya Nithiwat Tharathorn terdapat pesan-pesan yang ingin disampaikan oleh pengarang dalam karyanya, salah satunya adalah nilai didaktis yang bersifat mendidik dan memberikan teladan yang baik bagi para pembacanya melalui proses apresiasi karya sastra (Sundana et al., 2018). Hal ini sebagaimana definisi film yang merupakan alat penyampai berbagai jenis pesan pada zaman modern yang bersifat audio visual untuk menyampaikan informasi kepada khalayak (Fitriani, 2017; Nurmalasari, 2017). Berdasarkan hasil penelitian, maka terdapat sepuluh nilai didaktis yang terdapat dalam film The Teacher's Diary yang dapat dilihat pada tabel berikut:

Tabel 1. Hasil Temuan Nilai Didaktis

\begin{tabular}{|c|c|c|}
\hline No & Nilai Didaktis & Temuan Penelitian \\
\hline 1. & Nilai Intelektual/Kecerdasan & $\begin{array}{l}\text { 1. Kreatif Dalam Memperkenalkan Diri, } \\
\text { 2. Cerdas Dalam Menyelesaikan Masalah, Dan } \\
\text { 3. Cakap Dalam Mengajar. }\end{array}$ \\
\hline 2. & Nilai Keterampilan & $\begin{array}{l}\text { 1. Terampil Memanfaatkan Sesuatu, } \\
\text { 2. Mengajar Dengan Beri Penghargaan, } \\
\text { 3. Terampil Menyesuaikan Diri Dengan Lingkungan, } \\
\text { Dan } \\
\text { 4. Cepat Belajar. }\end{array}$ \\
\hline 3. & Nilai Harga Diri & $\begin{array}{l}\text { 1. Teguh Pendirian, } \\
\text { 2. Percaya Diri, Dan } \\
\text { 3. Mampu Memosisikan Diri Sebagai Guru. }\end{array}$ \\
\hline 4. & $\begin{array}{l}\text { Nilai Sosial/Hubungan } \\
\text { Masyarakat/Pergaulan }\end{array}$ & $\begin{array}{l}\text { 1. Bisa Bergaul Dengan Orang Lain, } \\
\text { 2. Saling Membutuhkan, } \\
\text { 3. Sikap Toleransi, Dan } \\
\text { 4. Bertanggung Jawab. }\end{array}$ \\
\hline 5. & Nilai Moral & Menegur Murid. \\
\hline 6. & Nilai Keindahan & Menyenangkan dan Menikmati Pemandangan. \\
\hline 7. & Nilai Ketuhanan/Keagamaan & Manusia Tetap Bergantung Kepada Tuhan. \\
\hline 8. & $\begin{array}{c}\text { Nilai Penguasaan Diri/Kestabilan } \\
\text { Emosi }\end{array}$ & Sabar \\
\hline 9. & $\begin{array}{c}\text { Nilai Tingkah Laku/Adat Sopan } \\
\text { Santun }\end{array}$ & $\begin{array}{l}\text { 1. Menyapa, } \\
\text { 2. Menghargai, } \\
\text { 3. Mengingatkan, Dan } \\
\text { 4. Bersikap Sopan. }\end{array}$ \\
\hline 10. & $\begin{array}{l}\text { Nilai Kehendak/Kemauan Atau Cita- } \\
\text { Cita }\end{array}$ & $\begin{array}{l}\text { Mampu Memotivasi Dalam Membentuk Cita-Cita } \\
\text { Murid. }\end{array}$ \\
\hline
\end{tabular}


Berdasarkan data di atas, terdapat nilai-nilai didaktis yang berkaitan dengan nilai intelektual/kecerdasan sebanyak 3 temuan, nilai keterampilan sebanyak 4 temuan, nilai harga diri sebanyak 3 temuan, nilai sosial sebanyak 4 temuan, nilai moral, nilai keindahan, nilai ketuhanan, dan nilai penguasaan diri sebanyak 1 temuan, nilai sopan santun sebanyak 4 temuan, serta nilai cita-cita sebanyak 1 temuan.

\section{Pembahasan Penelitian}

\section{Nilai Intelektual/Kecerdasan}

Nilai kecerdasan/intelektual adalah proses berpikir untuk menganalisis setiap masalah melalui pengamatan secara kreatif, logis dan kritis (Nurmalasari, 2017). Berikut adalah kutipan data dari nilai intelektual:

a. Kreatif dalam memperkenalkan diri.

Pada menit 00:10:58-00:11:31

Ann: "Baiklah. Halo anak-anak. Nama saya ANN.... A (menggunakan gerakan tubuh membentuk huruf $A$ )".

Gigi: "Apa kita harus membuat gaya?”.

Ann: "Ya, anak-anak lebih mudah mengingat gerakan tubuh."

Gigi: "Nama saya.... GIGI (menggunakan gerakan tangan menggelitik)".

Ann: "Oke sekarang anak-anak. Saya ingin semuanya memperkenalkan nama masing-masing dengan membuat gaya".

Data tersebut menunjukkan nilai intelektual yang ada pada tokoh Ann dalam membuat kesan pertama yang menyenangkan dan sekaligus memberikan pengajaran kepada anak-anak untuk lebih mudah mengingat apabila melakukan apapun dengan menggunakan gaya. Hal tersebut tergambarkan ketika Ann memperkenalkan diri dengan cara membuat gerakan tubuh.

b. Cerdas dalam menyelesaikan masalah.

Pada menit 00:26:58-00:27:10

Orang: "Setiap musim hujan kita selalu menemukan orang mati. Apa yang Anda pikirkan mengeluarkan mayatnya sendiri? Anda tidak takut?".

Ann: "Saya bukannya ingin menjadi artis Baywatch tapi akan membutuhkan waktu untuk memanggilmu dengan perahu dan kembali kesini. Anak-anak akan ketakutan".

Data tersebut menunjukkan nilai kecerdasan pada tokoh untuk mencari cara/solusi dari permasalahan yang dihadapi ketika tiba-tiba menemukan orang mati, yaitu dengan memberanikan diri untuk mengeluarkan mayatnya sendiri agar anak-anak tidak lagi takut.

c. Cakap dalam mengajar.

Pada menit 01:33:40-01:34:44

Ann: "Nui. Ada seorang guru lain di rumah kapal. Suatu hari dia mencoba mengajarkan soal matematika. Soalnya berhubungan dengan kereta. Ada satu anak yang kebingungan karena dia tidak pernah naik kereta sebelumnya. Jadi dia memutuskan mengikat rumah kapalnya di belakang perahunya seperti kereta. Apa pendapatmu tentang guru itu?".

Data tersebut menunjukkan nilai kecerdasan yang ada pada tokoh guru Song yang dibicarakan oleh guru Nui, yaitu ingin murid-muridnya bisa mengetahui rasanya naik kereta. Dengan cara menarik sekolah kapal yang diikatkan ke perahu agar murid-muridnya memiliki kesan tentang naik kereta sehingga terus diingat di kepala mereka dan memberikan pengajaran yang membuat murid-murid menjadi lebih mudah mengerti dalam menyelesaikan soal.

Berdasarkan uraian ketiga temuan di atas, menunjukkan nilai intelektual/kecerdasan yang dimiliki oleh guru di sekolah dalam proses pembelajaran serta menghadapi setiap permasalahan yang ditemui di sekolah.

\section{Nilai Keterampilan}

Nilai keterampilan adalah suatu nilai yang ada dalam diri manusia mengenai kemampuan untuk mencipta dan menghasilkan sesuatu sebagai kecakapan dan kepandaian mengerjakan sesuatu (Ali dalam Apriawati, 2016). Berikut adalah kutipan data nilai keterampilan:

a. Terampil memanfaatkan sesuatu.

Pada menit 00:07:21

Digambarkan di dalam film dimana keadaan di sekolah kapal yang tidak ada listrik lalu guru Ann menggunakan bahan-bahan rakitan dan aki agar ada lampu untuk penerangan. 
Berdasarkan data tersebut menunjukkan nilai keterampilan bahwa seorang guru harus mampu memanfaatkan apapun dalam segala keterbatasan yang dimiliki. Tidak mengeluh dan tetap berusaha mencari jalan dari berbagai permasalahan yang dihadapi seperti yang dilakukan guru Ann.

b. Mengajar dengan beri penghargaan.

Pada menit 00:30:41

Ann: "Siapa saja yang menyelesaikan duluan dengan benar akan dapat bintang".

Data tersebut menunjukkan nilai keterampilan bahwa guru harus mampu secara mandiri untuk menghidupkan suasana kelas dengan berbagai kegiatan yang menyenangkan serta membangkitkan semangat siswa belajar dengan memberi penghargaan.

c. Terampil menyesuaikan diri dengan lingkungan.

Pada menit 00:34:37

Pada menit ini, menggambarkan awal cerita saat datang ke sekolah kapal guru Ann tidak bisa berenang. Makanya apabila mau masuk ke air selalu menggunakan baju pelampung. Setelah lama mengajar di sekolah kapal, guru Ann belajar berenang bersama murid-muridnya sampai akhirnya bisa berenang.

Berdasarkan data tersebut menunjukkan nilai keterampilan bahwa dimanapun atau dalam setiap kondisi apapun kita sebagai guru harus cepat belajar dengan lingkungan yang kita tinggali dan guru Ann belajar berenang ditemani dengan murid-muridnya yang sudah pandai berenang.

d. Cepat belajar.

Pada menit 00:34:50.

Pada menit ini menggambarkan awal kedatangan guru Song ke sekolah kapal, dia tidak tahu kemana semua murid-murid di sekolah tersebut. Lalu, dia memutuskan untuk mencari murid-muridnya dengan menggunakan perahu yang ada di dekat sekolah kapal. Ketika ingin menjalankan perahu, guru song tidak berpegangan sehingga mengakibatkan tangannya patah. Setelah tangannya sembuh, guru Song belajar menggunakan perahu lagi dan akhirnya dia bisa mengendarai perahu dengan baik.

Berdasarkan data tersebut menunjukkan nilai keterampilan bahwa guru Song bisa memahami dengan cepat cara menggunakan perahu dengan benar dikarenakan daerah sekolah kapal yang berada di laut makanya mobilitas yang dilakukan harus menggunakan perahu.

Berdasarkan uraian ke empat temuan di atas, menunjukkan nilai keterampilan yang dimiliki oleh guru, mulai dari terampil dalam memanfaatkan sesuatu, terampil dalam mengajar, terampil dalam menyesuaikan diri dengan lingkungan, hingga terampil dalam mempelajari suatu hal yang baru.

\section{Nilai Harga Diri}

Nilai Harga diri merupakan kesadaran tentang besarnya nilai yang diberikan kepada diri sendiri, harga diri juga memiliki arti lain, yaitu kehormatan, martabat, atau harkat manusia (Kasanova and Oktasari, 2019). Berikut adalah kutipan data nilai harga diri:

a. Teguh pendirian.

Pada menit 00:00:42-00:01:23

Ann: "Sebagai kepala sekolah saya pikir Anda sudah keterlaluan. Anda menilai saya sebagai guru yang buruk karena hal sepele ini (sambil menunjukkan tato tiga bintang di lengan kanan). Bukannya anda seharusnya lebih memperhatikan hal yang lebih penting daripada apa yang ada di dalam pakaian saya?".

Kepala sekolah: "Hapus tatonya sekarang juga."

Ann: "Saya tak bisa melakukannya".

Kepala sekolah: "Ya, harus".

Ann: "Tidak, saya tak mau".

Data tersebut menunjukkan nilai harga diri seorang guru yang teguh terhadap pendirian pada diri guru Ann yang tidak mau menghapus tato yang ada dibalik bajunya. Maka, seorang guru harus memiliki prinsip dan teguh pendirian yang perlu dipertahankan dalam dirinya.

b. Percaya diri.

Pada menit 00:01:01-00:01:17

Kepala sekolah: "Sekarang posisi guru P.E kami sudah diisi". 
Guru Song : "Saya bisa menjadi asisten guru. Saya bisa membuat kerajinan tangan dan kesenian. Fotokopi, mengirim faks. Saya akan melakukan apapun”.

Data tersebut menunjukkan bahwa nilai percaya diri pada guru Song yang merasa dirinya pandai dalam membuat kerajinan tangan dan kesenian agar dapat menjadi guru P.E di sekolah. Ia meyakinkan kepala sekolah untuk bisa menjadi guru di sekolah tersebut. Hal ini menunjukkan bahwa guru Song memiliki nilai harga diri ataas dirinya.

c. Mampu memahami tugas guru.

Pada menit 00:19:23-00:19:39

Nui: "Kau hanya ingin membuktikan ke kepala sekolah kalau kau itu benar. Berada di tengahtengah antah berantah mengajar 4-5 anak, apa itu sepadan?".

Ann: "Yang bener 7. 7 anak". Kau juga seorang guru, bagaimana kau bisa bilang itu sepadan? dan sudah kubilang jangan. Bisakah kau berhenti mengucapkan itu?”.

Data tersebut menunjukkan nilai harga diri bahwa seorang guru tidak boleh mempermasalahkan berapa banyak atau sedikit murid yang dia punya akan tetapi tetap mengajar dengan sepenuh hati.

Berdasarkan uraian ketiga temuan di atas, menunjukkan nilai harga diri seorang guru yang teguh terhadap pendirian, percaya diri, serta memahami tugas guru harus tetap mengajar tapa melihat jumlah siswanya.

\section{Nilai Sosial}

Nilai sosial terbagi menjadi beberapa indikator, di antaranya yaitu: nilai yang berkaitan dengan kesadaran akan hak dan kewajiban, nilai yang berkaitan dengan rasa tanggung jawab, dan nilai yang berkaitan dengan sikap toleransi (Fitriani, 2017). Berikut adalah kutipan data nilai sosial:

a. Bisa bergaul dengan orang lain.

Pada menit 00:03:08

Ann: "Apa tak ada sinyal ponsel disekitar sini?"

Nelayan: "Agak sedikit susah. Kalau harinya cerah sinyalnya ada. Tapi saya tak tahu berapa banyak hari cerah yang kami punya dalam setahun".

Ann: "Kau lucu".

Data tersebut menunjukkan nilai sosial bahwa sebagai manusia kita perlu interaksi dengan orang lain juga. Apalagi sebagai orang yang baru pertama kali datang ke suatu daerah, kita perlu bertanya untuk mengetahui situasi tempat yang kita datangi.

b. Saling membutuhkan.

Pada menit 00:08:26

Ann: "Kalau sudah sampai pantai, telepon nomor ini. Katakan ke seseorang saya sudah sampai" (berbicara dengan nelayan).

Data tersebut menunjukkan nilai sosial bahwa kita sebagai manusia juga membutuhkan manusia lainnya. Saat sedang berbelanja kebutuhan makanan, guru Ann meminta bantuan kepada nelayan karena akses untuk pergi kemanapun sangat terbatas.

c. Sikap Toleransi.

Pada menit 00:45:02-00:45:52

Ann: "Tapi hari ini ujian akhir semesternya. Kalau dia tidak ujian, dia takkan lulus SD. Dia tidak akan bisa melanjutkan pendidikannya dimanapun".

Ayah Chon: "Itu tidak apa-apa".

Ann: "Tidak. Anda ingin anak Anda memancing ikan seumur hidupnya?".

Ayah Chon: "Bu Ann, Kalau saya tidak pergi memancing, bagaimana saya memberi makan keluarga saya?".

Ann: "Saya mengerti Anda harus menafkahi keluarga Anda. Tapi kalau seorang anak ingin sekolah, itu sudah menjadi haknya. Anda merusak kesempatannya...

Data tersebut menunjukkan nilai sosial bahwa guru Ann berusaha untuk Chon tetap sekolah dan tetap memberikan pengertian kepada ayah Chon walaupun harus toleransi dengan keputusan yang dibuat oleh ayahnya Chon.

d. Sikap tolong menolong.

Pada menit 00:47:30 
Song: "Saya di sini untuk meminta Chon untuk kembali sekolah (mengarah ke Ayah chon). Chon, ikut denganku ke sekolah. Kau bisa menolong Ayahmu nanti. Kalau sekolah, tak ada yang bisa menipumu" (bicara kepada Chon).

Ayah Chon: "Dia sudah tidak sekolah hampir setahun. Tidak ada yang mau menerimanya kembali".

Song: "Jangan khawatir. Saya kenal kepala sekolahnya. Kami sangat dekat seperti keluarga. Saya guru favoritnya kepala sekolah".

Ayah Chon: "Kalau dia sekolah, siapa yang akan menolongku memancing?"

Song: "Saya akan menolongmu, jangan khawatir soal itu. Kalau sudah waktunya memancing, saya akan membantumu. Saya akan membantu anda memancing setiap akhir pekan".

Ayah Chon: "Jadi akhir pekan nanti Anda tidak pulang?".

Song: "Tidak usah khawatirkan itu, tidak masalah. Malah lebih baik. Saya bisa menabung lebih banyak uang karena tidak perlu membayar sewa kamar".

Data tersebut menunjukkan nilai sosial pada diri guru Song yang membantu pekerjaan ayahnya Chon agar Chon dapat bersekolah. Di lain sisi, ayah Chon juga menolong guru Song dengan menyediakan tempat tinggal, sehingga ia tidak perlu menyewa kamar untuk tidur.

Berdasarkan uraian keempat temuan di atas, menunjukkan nilai social pada diri seorang guru yang mudah bergaul, saling membutuhkan, sikap toleransi, dan sikap tolong menolong sesama manusia.

\section{Nilai Moral}

Nilai moral adalah hubungan dalam pergaulan masyarakat dan hubungan itu ada ukuranukurannya yaitu ukuran mengenai nilai baik dan buruk (Ali dalam Apriawati, 2016). Kutipan data nilai moral sebagai berikut:

a. Menegur murid.

Pada menit 00:15:23

Song: "Apa yang kalian lakukan di sana? Siapa yang mengizinkan kalian main air? Naik sekarang! "Jangan membuat alasan apapun. Bagaimana kalau salah satu dari kalian tenggelam? Apa saya harus mengawasi kalian setiap waktu”.

Tuna: "Kami semua sudah bisa berenang".

Song: "Bagaimana kalau kalian kram?".

Tuna: "Tidak mungkin, kami sudah berenang sejak di hari kami dilahirkan".

Song: "Jangan membantah. Skot jump 20 kali".

Tong: "Saya tidak tahu bagaimana caranya. Tolong jelaskan?".

Song: "Lihat saya". (mencontohkan tapi gagal)

Anak-anak tertawa

Muek: "Lompatan Scotch-Brites anda terlihat lucu”.

Song: "Buka tangan kalian. Berikan tangan kalian.

(memukul satu-satu tangan muridnya dengan rotan)

Data tersebut menunjukkan nilai moral bahwa sebagai seorang guru. Guru Song harus mengajarkan apa yang baik dan tidak baik dilakukan bagi diri murid-muridnya dan juga karena murid-muridnya memiliki tanggung jawab atas diri mereka terhadap apa yang sudah dilakukan.

\section{Nilai Keindahan}

Nilai keindahan adalah hal yang diinginkan manusia agar hidupnya menjadi lebih halus, menyenangkan dan menimbulkan kenikmatan (Ali dalam Apriawati, 2016). Kutipan data nilai keindahan:

a. Menyenangkan dan menikmati pemandangan.

Pada Menit 00:04:11

Gigi: "Segar sekali. Ayo foto bareng, buat kenang-kenangan".

Data tersebut menunjukkan nilai keindahan bahwa guru Ann dan guru Gigi menikmati suasana sekolah kapal dan merasa senang. 


\section{Nilai Ketuhanan}

Nilai ketuhanan pada dasarnya adalan pedoman-pedoman atau motif-motif kerohanian yang dimiliki oleh manusia untuk memenuhi kebutuhan rohani atau batin (Kasanova and Oktasari, 2019). Kutipan data nilai ketuhanan sebagai berikut:

a. Manusia tetap bergantung kepada Tuhan.

Pada menit 00:26:47

Pada menit ini ditemukan ada mayat di bawah toilet membuat anak-anak di sana ketakutan. Di dalam film, digambarkan dengan memanggil seorang pendeta untuk mendoakan sekitar toilet dengan tradisi dan kepercayaan agama. Guru Song juga melakukan gerakan-gerakan berdoa.

Data tersebut menunjukkan bahwa setiap manusia memiliki ketakutan. Maka manusia memerlukan pegangan dalam hidupnya yaitu agama/tuhan. Dengan bersandar pada Tuhan maka semua kejadian yang terjadi bisa menenangkan hati dan mencapai kebahagiaan yang abadi.

\section{Nilai Pengendalian Diri/Kestabilan Emosi}

Nilai pengendalian diri ini terkait dengan individu mampu mengendalikan/mengontrol diri dengan baik dan harmonis dalam bertindak dalam kehidupan masyarakat (Pradina dalam Kasanova and Oktasari, 2019). Kutipan data nilai pengendalian diri:

a. Sabar.

Pada menit 00:27:14

Gigi: "Ayo pergi Ann. Aku sudah mengemasi barang-barang kita".

Ann: "Kau mau pergi begitu saja?".

Gigi: "Berikan aku alasan yang benar untuk tinggal disini. Kemarin malam ada cicak di air kita. Sekarang kita menemukan mayat. Berapa lama lagi kita harus bertahan?

Ann: "Tapi kalau kita pergi, kepala sekolah akan menutup tempat ini."

Gigi: "Terus kenapa?”. Terserah, aku tetap mau pergi".

Menjadi guru bukan saja tentang $A, B, C$ dan 1, 2, 3. Siapa yang menyangka sebuah tato tiga bintang akan membawaku sejauh ini?

Data tersebut menunjukkan bahwa nilai pengendalian emosi ada pada tokoh guru Ann.

Tetap sabar dengan berbagai masalah yang dihadapi dan ingin semua murid-muridnya tetap bersekolah agar menjadi anak yang pandai.

\section{Nilai Tingkah Laku/Adab Sopan Santun}

Nilai tingkah laku atau adab adalah perubahan tingkah laku, budi pekerti, akhlak dan watak ke arah yang lebih baik melalui kegiatan pengajaran (Ali dalam Apriawati, 2016). Berikut adalah kutipan data dari nilai tingkah laku:

a. Menyapa.

Pada menit 00:09:22-00:09:34

Song: "Halo (sambil menunduk dan merapatkan kedua telapak tangan menghadap ke lawan bicara)". Kau tahu anak-anak yang belajar di sini?".

Data tersebut menunjukkan nilai tingkah laku yang terletak pada tokoh guru song yang harus menghormati dan menyapa orang saat bertemu.

b. Menghargai.

Pada menit 00:10:46

Murid-murid: "Selamat pagi Bu guru".

Data tersebut menunjukkan nilai adab yang dimiliki murid kepada gurunya bahwa murid harus menghargai gurunya di depan kelas dengan mengucapkan salam.

c. Mengingatkan.

Pada menit 00:33:36

Song: "Muek jangan makan telur mentah, nanti kena diare".

Data tersebut menunjukkan nilai tingkah laku bahwa yang dilakukan muridnya itu tidak baik. Maka guru Song mengingatkan muridnya untuk tidak memakan telur yang masih mentah.

d. Bersikap sopan.

Pada menit 00:47:15-00:47:27

Song: "Halo (sambil menunduk dan merapatkan kedua telapak tangan menghadap ke lawan bicara) Ini rumahnya Chon?".

Ayah Chon: "Iya, benar". Ada apa?". 
Song: "Saya ingin mengenalkan diri saya. Saya Song. Saya guru di rumah kapal".

Data tersebut menunjukkan bahwa nilai tingkah laku/adab sopan santun harus dimiliki guru ketika bertemu orang tua murid atau siapa pun agar saling menghormati satu sama lain.

Berdasarkan uraian ke empat temuan di atas, menunjukkan nilai tingkah laku ataupun adab sopan santun baik pada diri seorang guru, maupun siswa. Hal ini terlihat dari sikap saling menyapa, menghargai satu sama lain, saling mengingatkan, serta sikap sopan santun.

\section{Nilai Kehendak/Kemauan/Cita-cita}

Nilai kehendak/cita-cita adalah keinginan dan motivasi dari individu untuk meraih apa yang dicita-citakannya (Ali dalam Apriawati, 2016). Kutipan data nilai kehendak/cita-cita:

a. Mampu memotivasi dalam membentuk cita-cita murid.

Pada menit 01:27:29-01:28:07

Ann: "Anak-anak sini, ibu mau mengatakan sesuatu. Ibu mau bilang kalau kalian lulus ujian. Semuanya lulus dan naik kelas".

Ann: "Ini dia (sambil memberikan rapot)".

Muek: (menerimanya)

Ann: "Ini tong".

Tong: "Terima kasih".

Ann: "Ini Tuna".

Tuna: "Terima kasih".

Ann: "Gao".

Gao: "Terima kasih".

Ann: "Kau akhirnya lulus. Kau lakukan yang terbaik untuk menolong ayahmu memancing, oke?”.

Chon: "Tidak perlu mengkhawatirkan itu. Aku akan menjadi nelayan yang sangat pintar matematika disini!".

Data tersebut menunjukkan bahwa tokoh guru Ann sebagai seorang guru di sekolah kapal tersebut dapat memotivasi murid-muridnya untuk meraih cita-citanya. Salah satu kebanggaan bagi guru Ann apabila ada kehendak atau cita-cita yang ingin dicapai oleh tokoh Chon atas semua yang telah diajarkan.

\section{Simpulan}

Berdasarkan hasil dan diskusi di atas, dapat disimpulkan bahwa dalam film The Teacher's Diary karya Nithiwat Tharathorn terdapat sepuluh nilai didaktis, antara lain: nilai intelektual/kecerdasan, nilai keterampilan, nilai harga diri, nilai sosial/hubungan masyarakat/pergaulan, nilai moral, nilai keindahan, nilai ketuhanan/keagamaan, nilai penguasaan diri/kestabilan emosi, nilai tingkah laku/adat sopan santun, nilai kehendak/kemauan atau cita-cita. Dengan rincian sebagai berikut:

1. Nilai intelektual/kecerdasan, antara lain: (a) kreatif dalam memperkenalkan diri, (b) cerdas dalam menyelesaikan masalah, dan (c) cakap dalam mengajar.

2. Nilai keterampilan, antara lain: (a) terampil memanfaatkan sesuatu, (b) mengajar dengan beri penghargaan, (c) terampil menyesuaikan diri dengan lingkungan, dan (d) cepat belajar.

3. Nilai harga diri, antara lain: (a) teguh pendirian, (b) percaya diri, dan (c) mampu memosisikan diri sebagai guru.

4. Nilai sosial, antara lain: (a) bisa bergaul dengan orang lain, (b) saling membutuhkan, (c) sikap toleransi, dan (d) bertanggung jawab.

5. Nilai moral, yaitu menegur murid.

6. Nilai keindahan, yaitu menyenangkan dan menikmati pemandangan.

7. Nilai ketuhanan, yaitu manusia tetap bergantung kepada tuhan.

8. Nilai pengendalian diri, yaitu sabar

9. Nilai tingkah laku, antara lain: (a) menyapa, (b) menghargai, (c) mengingatkan, dan (d) bersikap sopan.

10. Nilai cita-cita, yaitu mampu memotivasi dalam membentuk cita-cita murid.

Hasil temuan mengenai nilai didaktis di atas, dapat dijadikan sebagai contoh atau motivasi bagi calon guru ataupun guru dalam mendedikasikan dirinya untuk mengajar dan mendidik siswa di sekolah. 
Bagaimanapun juga, guru perlu mengetahui cara mengajar dan mendidik yang tepat dan baik agar siswa memiliki ketertarikan atau minat untuk selalu belajar dalam mencari ilmu bagi masa depan mereka.

\section{Ucapan Terima Kasih}

Kami ucapkan terima kasih kepada semua pihak yang telah berkontribusi dalam terlaksananya penelitian ini hingga akhirnya dapat terselesaikan dengan baik. Kontribusi yang dilakukan seperti memberi masukan, kritik dan saran sehingga penelitian ini menjadi lebih baik.

\section{Daftar Rujukan}

Anggriani, Meri, et al. "Analisis Nilai Kependidikan Dalam Film Akeelah And The Bee Karya Doug Atchison." Pena, vol. 2, 2015, pp. 371-79.

Apriawati, Nina. Nilai-Nilai Didaktis Novel Sang Pencerah Karya Akmal Nasery Basral Dan Pembelajarannya Di Sekolah Menengah Atas (SMA). Dec. 2016, doi:10.1128/AAC.03728-14.

Endeh. Nilai Didaktis Dalam Novel Hujan Karya Tere Liye. 2017, pp. 164-72.

Fitriani Leni. Nilai Didaktis Pada Film Jenderal Soedirman. 2017, pp. 254-61.

Kasanova, Ria, and Anisa Fajriana Oktasari. Nilai- Nilai Didaktis Dalam Novel " Matahari Di Atas Gilli ” Karya Lintang Sugianto. no. 2, 2019, pp. 47-58, doi:10.33603/dj.v6i2.1695.

Nurmalasari Irena. "Nilai Didaktis Pada Film Merry Riana Mimpi Sejuta Dolar." Diksatrasia, vol. 1, 2017, pp. 249-53.

Riyadi, Sugeng. "Penggunaan Film Adaptasi Sebagai Media Pengajaran Sastra." Jurnal Pendidikan Bahasa Dan Sastra, vol. 14, no. 2, 2014, pp. 241-51, doi:10.17509/bs_jpbsp.v14i2.722.

Sari, Ayu Puspita Indah, and Hastari Mayrita. Kajian Nilai Didaktis Cerita Rakyat Sebagai Konstribusi Penyusunan Bahan Bacaan Peserta Didik Dalam Buku Teks Bahasa Indonesia. 2017, pp. 1-11.

Sundana, Lina, et al. "Sastra Didaktis Dalam Pembelajaran Apresiasi Sastra." Riksa Bahasa, 2018, pp. 1085-93, doi:10.1017/CBO9781107415324.004. 